\title{
Research on Bilingual Teaching in Colleges and Universities in China
}

\author{
Jian Li \\ School of Foreign Languages, Northeast Petroleum Institute, Daqing 163318, China \\ Kunming Yao \\ School of Foreign Languages, Daqing Normal University, Daqing 163712 China
}

\begin{abstract}
Connotative development is significant in the instruction of university educational philosophy. Bilingual teaching has been considered as an important aspect of connotative development in colleges and universities. This thesis introduces the basic process of the development of bilingual teaching in colleges and universities in China. Bilingual teaching in colleges and universities in China began and gradually has become popular in colleges and universities from 2001, whose purpose is to cultivate to cultivate compound talents with both professional and foreign language ability, as well as international awareness and intercultural communicative competence. According to the survey, bilingual teaching in science, technology, economy, law etc. is more perfect, but Chinese culture, sociology, history courses almost have no bilingual teaching curriculum in universities in China. In the current globalization atmosphere, the impact of national political, economic, and cultural development influences the development of the world. Bilingual teaching in colleges and universities will play an important role in spreading the spirit of the times and cultivating students' national consciousness.
\end{abstract}

Index Terms-bilingual teaching, communication consciousness, cultivation

\section{INTRODUCTION}

Bilingual teaching involves in education in ensuring the students to pay attention to the content concerning with science, mathematics, and sociology while learning foreign language. Students like to learn knowledge in native language, and for foreign language learning they just like to learn language skills, the language teachers also possess this kind of ideas, that is to say language teaching become an only language skills teaching. Many researchers thinks bilingual program should help students to learn more in the foreign language classrooms, the linguistic goal of bilingual programs is not foreign language learning only, the students can use language skills to acquire academic knowledge in other field. This is the purpose for bilingual Education.

There are some famous researches about bilingual teaching. The very popular one is in Two-Way or Dual Language Immersion Bilingual Education. These are the programs of helping native or non-native speakers become biliterate and bilingual during learning foreign languages. This program is mainly based on the principle of clear separation of curriculum by instruction of two languages. Teachers do not repeat or translate the subject matter in second language but strengthen concepts taught in one language across the two languages in a spiral curriculum in order to provide cognitive challenge (Thomas \& Collier, 1997, p.23-26). The languages of instructions are alternated by theme or content area. This type of immersion is required to develop the dual language proficiency, as social language can be mastered in couple of years, but a higher level of competency is required to read social studies texts or solve mathematics word problems, roughly around 5 to 7 years (Collier, 1987).

The advantage of Dual Immersion classrooms is that it can encourage students to maintain the enthusiasm of foreign language learning and to pay much attention of the function of language learning. Dual Language programs researcher point out that they are extremely effective in helping students learn English well and aiding the long-term performance of English learners in school. Native English speakers benefit by learning a second language. English language learners (ELLs) are not segregated from their peers.

There are also other forms of Bilingual Education, such as they can make the students study in two different ways: Firstly, different kinds of academic subjects can be taught in second language, this need the teachers have trained bilingual in a special way, for the teachers, they can understand the question of the students in their native language, and can also answer these question in the second language for the students; and secondly, the researcher also suggested that the student should learn their writing and higher-order language skills in native language literacy classes. Skills learned in the first language can be easily changed to the second language.

\section{BiLINGUAL TEACHING IN DifFERENT COUNTRIES}

In Argentina the local Elite used Irish, and there are many English-Spanish schools in Argentina. In Australia the government supports bilingual programs in school education. Take Bilingual education in the Northern Territory, for 
example, in the early 1970s, Federal Government begin to support bilingual programs for Indigenous students. The government allowed most bilingual programs of two-way education. As Harris \& Devlin observe, "Aboriginal bilingual education in Australia represents much more than a range of education programs. It has been a measure of non-Aboriginal commitment to either assimilation or cultural pluralism" (Harris \& Devlin, 1986, p.14). The official bilingualism in Canada is English and French. The federal government likes to support to establish bilingual country in Canada. For this reason the government helps the public education systems to establish French immersion programs in Canada. But now in Canada there is still the phenomenon that school education is monolingual, it is either English or French. The second official language is introduced with a minimal amount of allocated time provided each week in the form of just one single subject. Bilingual programmes in Canada combine English, with French, or both. Different places will have different policies bilingual programmes. This is gradually being established and makes bilingual programmes exist in many places. Up to 2010 , new programmes encounter the fanatical dilemma in the process of processing.

Language policy in France has its own characteristic. French is the sole official language in France, difference region has provincial languages. The bilingual education programmes elective courses of regional language and French are established. Because of the French-language policy, the national government will give no funding towards any of these programmes.

Hindi is official language in India, there are also 21 regional languages have co-official status, so Three-language formula of Education in India is very popular, the children in India are to be taught Hindi, English and the regional language. Schools in India have the freedom to decide which languages are taught; parents favor English-medium schools, especially in cities in India, Because English is used in Indian business and in most Indian universities English is medium of instruction.

\section{General Survey of Bilingual Teaching In Colleges and Universities in China}

In China many public schools of major ethnic minorities use the local language as medium of instructions, such as e.g. Uyghur or Tibetan, and Chinese is also a very important medium in school teaching. Traditionally, the textbooks there were little different from merely a translated version of the books used in the Chinese schools throughout the country; based on this purpose, teaching materials are created more with locally based content as well as in Chinese. Chinese is offered in these minority schools, the government makes efforts to make them effective. Here we talk about bilingual teaching based on the students in universities and colleges. It will not only learn some knowledge in Chinese and English as well, in order to make the students to adapt to the internationalization process. To take the research papers in resent years as an important data, to study on bilingual teaching to present bilingual teaching research status during the resent ten years, analyze the data, we get the advantages and disadvantages of bilingual teaching in universities and colleges. We found out the shortcomings of bilingual teaching in universities and colleges in China, and then get the idea about the suggestions for the further research in bilingual teaching. Bilingual teaching program focuses on the development of the students' ability of communication not only national as well as international.

Bilingual teaching in universities from the theory of connotative development of university has been written into the report to the Eighteenth National Congress of the Communist Party of China that has directive significance to the institutions' operation principles and education philosophy of higher learning. In order to realize the connotative development, universities persist in widen the vision and accelerating the development. Bilingual teaching in colleges and universities has been looked as an aspect of connotative development all the time, and it's already become a very important evaluation. The bilingual teaching in our country begins from September 2001. The Ministry of Education proposed an idea that colleges and universities should further the development of various courses teaching by foreign language such as English in the document named Several Ideas On Strengthening Undergraduate Teaching And Improving Teaching Quality Of Colleges And Universities. However, bilingual teaching has a long history abroad. The Longman Dictionary of Applied Linguistics and Teaching defines it as "the use of second language or foreign languages in school for the teaching of content subjects." (Richards, J.C. \& Schnide, R., 2003) In Chinese it means "teaching by second language or foreign languages in school". Two famous Canadian experts $-\mathrm{M} \cdot \mathrm{F} \bullet$ Mackay and $\mathrm{M} \cdot$ Seeger -wrote a book called The Introduction of Bilingual Education in which they proposed that "bilingual teaching is a kind of system used two languages as instructional medium, and one language of them often but not must be the first language of students". These are narrow definition (the former) and broad definition (the latter) of the Bilingual teaching $(\mathrm{M} \cdot \mathrm{F} \bullet$ Mackay and $\mathrm{M} \cdot$ Seeger, 1989).

Bilingual teaching in colleges and universities is an important indicator on connotative development. Connotative development of university contains not only the development trend and development pattern of schools, but also the training method and effect of students. Moreover, bilingual teaching in universities plays a positive role in training students' academic quality and interior quality.

Bilingual courses gradually began in colleges and universities since 2001.It aims to educate more inter-disciplinary talents who have professional quality and foreign language ability, and international awareness with intercultural communicative competence. At the end of last century, bilingual teaching came in vogue in Chinese colleges and universities. Until the beginning of the present century, bilingual teaching has been the hotspot in educating high-qualified talents, advancing educational reformulation, and creating education with special characteristics in 
schools. Bilingual education in colleges and universities formed a kind of teaching model which based on immersion model and transition model. Bilingual teaching takes nature science teaching as leading course, because it has slight cultural differences and few national boundaries, and used in international communication normally. Particularly some areas that developed well abroad such as biology, life science, computer science, and medical science and so on, they all adopt English language teaching directly. Some schools even use original English venison as textbooks directly, providing an accurate picture of the forward trends of these areas and also makes students understand the international situation of the research in these fields better. In addition, bilingual teaching is expanding by leaps and bounds in the specialty of economics and management. Since the accession to WTO, China's political, economic and legal system has been geared to international standard. This requires that the builders of the 21 st century have to understand international economic development trends and laws and regulations, for economic development in China interconnecting with global economy. Therefore, not only in the course of science and engineering, but also in the courses of arts such as law, economics and management, the bilingual teaching has already developed quite perfectly. However, investigation revealed that there're also some problems existed in these courses' bilingual teaching.

1. Shortage of teachers. Because of the bilingual teaching in colleges and universities requires high personal qualities of teachers. Both skilled foreign languages capacity and a high level of professional quality are important. Neither of the two can be dispensed. Bilingual teaching is not equal to language courses, but the courses that learn specialized knowledge by foreign language. So, first of all, only the ones who can become the compound-type talents that skilled in foreign language and specialized knowledge can be competent for the task of bilingual teachers.

2. Bilingual teaching materials are not perfect. Many bilingual curriculum use original edition of textbooks, however, such materials are pretty difficult that both teachers and students have many questions when they teaching and learning. Some schools use self-compiled textbooks, but these ones are not fully enough in compilation system and professional knowledge.

3. The foreign languages level of some students becomes a major bottleneck of bilingual teaching. Many students' English ability gets in the way of their bilingual courses learning. Some students are weary of foreign language learning which will inevitably have negative influence on bilingual education.

The survey about courses that offered by bilingual teaching has revealed a phenomenon that there are few bilingual teaching in courses such as Chinese culture, sociology, and history. According to the survey, bilingual education system in Beijing University is complete. The arts courses that Bejing University offered such as Institute of international relations, History Department's 11 courses, Institute of economics' courses "Advanced Econometrics", "economy", "macroeconomics", "insurance", "Investment Bank" are all bilingual or English teaching. About 60\% courses in Guanghua School of Management use original edition of textbooks in foreign languages, and there're 34 courses used bilingual teaching in the all 64 courses of 2005-2006 academic years. And in Department of Philosophy, there are 19 courses carried out the mode that external teachers and teachers in Beijing University teach students together. The mature development of bilingual teaching in Beijing University is inseparable from school's educational philosophy and teachers' and students' quality.

There are also some data about bilingual courses in other universities, which enables us to see that bilingual teaching in literature and history classes really need to be developed. Referred to the universities which offer bilingual teaching courses, we can cite examples as follows: Shandong University only operates bilingual courses such as International Economic Law, Labor Law, Tourism and Culture. Community College in Suzhou University offers United States History, Social Statistics Software, Modern Tourist Reception Point, Contemporary Relations Studies; College of Politics and Public Administration offers History of Western Ethics, Management, Management Information Systems, International Politics; Institute of Foreign Languages offers Chinese Traditional Culture. Institute of Management in Shenyang Industrial University offers Project Investment and Financing; Institute of Economics offers Information economics, Business Correspondence, Commercial Banks, International Finance, Corporate Finance and other courses. These bilingual courses of liberal arts in Colleges and universities mostly focus on the areas of economics, management and law. As to philosophy courses are only available in the universities which have high level of internationalization such as Beijing University, the bottleneck is mainly concentrated in the two aspects that students' quality and instructional resource.

\section{Blind Spot of Bilingual Teaching in Colleges and Universities}

Bilingual teaching has been one of the most important indicators of evaluation in universities, therefore the present universities bilingual teaching is developing toward the direction of standardization, matured and systematic. But in the process of investigation we found that Chinese traditional and modern culture and the spirit of the age related courses are not in bilingual forms, including introduction to Mao Zedong thought, the Chinese characteristic socialism courses never have been taught in bilingual forms in universities. And only a few universities opened the bilingual classes about the traditional culture of China. This shows that Chinese culture, the spirit of the Chinese nation and Chinese sociology are the blind spots of bilingual teaching. Bilingual teaching researchers think these are pure Chinese literature, history and philosophy discipline, using bilingual teaching is unnecessary, just painting the lily.

The reasons of the blind spot in bilingual teaching are as following: 1. Majority of university curriculum researchers think that the purpose of bilingual teaching is to absorb the international advanced idea and advanced thought, the 
courses concerns pure Chinese point involved in the problem of the international idea. 2. There are some based attitude to Chinese philosophical theory and traditional culture. The theory only applies to the social system in China and it doesn't have international significance. 3. The strong time and political color of Chinese culture make the modern philosophy and the spirit of the age become more national than international.

Based on above reasons, bilingual teaching emerged some blind areas in Chinese culture, philosophy and the spirit of the age. We should consider what kind of influence that the blind areas will bring to the education of students. Now education popularizing rate in our country becomes higher and higher. In 2012 college entrance examination admit 6.85 million students with 9.15 million candidates. Admission rate is $75 \%$. We see that college graduates have become the mainstream of social youth employed from such a high rate. So, it's very necessary to train undergraduates' cultural consciousness and cultural communication ability for the spirit of the age of international communication.

\section{Significance of Bilingual Teaching in Colleges and Universities to the Communication of The SPIRIT OF THE AGE}

With the rapid development of the world economy, globalization has brought impact to national political, economic and cultural development. China successfully entered the WTO organization under the background of globalization. It shows that China has it own harmony in the mainstream of globalization. China does not close the country to international intercourse any more, but began to move towards the world. In this process, China participate in globalization actively, its purpose is to realize the faster, better and more rapid development, realizing the great rejuvenation of the Chinese nation. Marx had a claim that "the communist revolution will not only a country's revolution, but will in all civilized countries, at least in Britain, France, Germany would all happen revolution... it is a worldwide revolution, so there will be worldwide activity places."(Marx \& Engels, 1995, p. 241) Western powers in the global situation also constantly colonial expansion and modern western civilization of global communication process is consistent. The globalization process means the human social life and activity space is not limited to national sovereignty territory boundaries. The content of the globalization is not only related to trade, the financial sector, but also including political, cultural, legal and social life in all areas. The rapid development of globalization, China's political, economic and cultural has begun to fusion in the world scope, it must be clear and definite that globalization is not homogeneous, that is, globalization is not invasion and annex, but heterogeneous, is the spread of advanced culture and identity. The eighteenth big report puts forward the overall objectives of development in our country; this paper puts forward to the great rejuvenation of the Chinese nation as the goal of building socialism with Chinese characteristics strategy. In China the construction of socialism with Chinese characteristics of thirty years, China created the Chinese miracle, China mode and China road, these beautiful Chinese stories have been attentive by the world, more and more Chinese phenomenon researchers began to pay attention to development in China.

Under such a background, cultivating the students' cultural consciousness and culturing communication ability is necessary: 1. A few years later the college students will be the main members of building socialism in the coming future, the mainstay of their cultural consciousness and cultural transmission capacity will affect the spread of Chinese culture. 2. Spreding of culture has huge influence on the great rejuvenation of the Chinese nation and the realization of the dream of the Chinese nation's worldwide rise. 3. The spirit of The Times of the Chinese nation is a precious spiritual wealth of the world civilization. It is also the basis of depth dialogue in the process of globalization in China and other countries. 4. Cultural consciousness and communication of university student is the premise of the realization of spreading the spirit of the age of Chinese nation. 5. Bilingual teaching in universities in China is the effective way to cultivate cultural transmission ability of university students.

\section{Bilingual Teaching in Colleges and Universities Should Cultivate National Consciousness of STUDENTS}

As mentioned above, our country's bilingual teaching in college ideological and political courses has a blind spot. The ideological and political theory courses have 4 required courses: introduction to the basic principle of Marxism, Mao Zedong thought, Deng Xiaoping theory and the important thought of Three Represents introduction, Chinese modern history outline, Thought morals tutelage and legal foundation. Moreover, there is the compulsory course: Situation and Policy and the elective course: Contemporary World Economy and Politics offered. According to The CPC Central Committee Propaganda Department, the Ministry of Education on Further Strengthening and Improving the High Ideological and Political Theory Course Opinion and the requirements of the scheme, from 2006 autumn began to implement the new scheme of ideological and political theory course, the purpose is to adhere to the socialist direction of education, cultivating the socialist modernization construction of the qualified builders and successors. The university thought politics theory class setting with strategic position is to achieve the teaching purpose of running an important means, but also develop the socialist builders and reliable successors of effective way. The university thought politics theory class has been centered on the socialist core value system to lead, in the practice of socialist core value system is duty-bound responsibility, in order to achieve the university education "teaching, personnel training, teach heart, teach character". 
The universities believing politics theory class plays a positive role to help students establish the scientific worldview, the outlook on life and values, to cultivate university students' moral consciousness, moral feeling, moral belief, moral behavior and habits, to cultivate college students' sense of responsibility.

In view of the ideological and political theory in college students' ideology mature process function, the positive significance of suggesting open the ideological and political course of bilingual teaching lies in: 1 . To learn about the world on Marxism classical theory and trends. 2. To understand foreign scholars on research situation of Chinese sociology theory. 3. To cultivate the spirit of the nation consciousness of students, strengthen the sense of pride of the Chinese nation. 4. Bilingual teaching of university ideological and political theory can also promote the development of international studies. 5. To improve the contemporary sense of spreading the spirit of the age and awareness communication ability.

\section{CONCLUSION}

The reasons that the bilingual teaching of ideological and political education becomes the blind spot of bilingual teaching in China are as following factors: 1. No corresponding materials. The original works of the Marxism classical theories are too much difficult, and it is not suitable for teaching directly. Outline of Chinese modern history, There are no corresponding English versions of the teaching material of Thoughts of Mao Zedong and introduction to theoretical system of socialism with Chinese characteristics, situation and policy course etc. 2. Obsolete idea possesses teachers. Chinese unique characteristics of ideological and political theory system make a lot of teachers hold a view that Chinese ideological and political theory does not comply with the international development trend, there's no practical significance to make bilingual teaching. 3. The sense of Times is not strong. The ideological and political education is based on the classical theory and philosophical history teaching as the main content, which makes students feel old and obsolete.

In view of this situation, how to make bilingual teaching of ideological and political adapt to the development of times, let the bilingual teaching of ideological and political become a real time spirit communication, national international identity, Chinese modern civilization and the depth of the world civilization, is an important dialogue and urgent problem to be solved: first, organize teachers with high level to write compound teaching's material for bilingual teaching of ideological and political, in order to solve the problem of shortage of teaching material in classroom. Second, to change the idea of teachers, make them realize in the process of Chinese economic booming the world begin to pay attention to China, Thought of Mao Zedong, Theory of Deng Xiaoping and the important thought of three represents, and the scientific concept of development have played a positive role in guiding the development in China. These Chinese characteristics socialism theories become spiritual treasure of humanity. We have an obligation to spread these thoughts to the world. Moreover, rapid economic development in China has made China become second biggest economy country and the world pays much attention to the development of China. More and more people like to know Chinese model and Chinese road. In this case, the spirit of the age has become important spiritual wealth in the world, so the cultivation of cultural consciousness of student and bilingual teaching of ideological and political for students become Chinese consciousness of the spirit of times in China.

\section{REFERENCES}

[1] Collier, Virginia P. (1995). Acquiring a Second Language for School. Directions in Language \& Education - National Clearinghouse for Bilingual Education, 1, 8-25.

[2] Harris, S.G. \& Devlin, B.C. (1996). Bilingual programs involving Aboriginal languages in Australia. Encyclopedia of language and education, vol 5, p. 1-14.

[3] Marx \& Engels. (1995). Selected works of Marx and Engels. Beijing: people's publishing house.

[4] $\mathrm{M} \cdot \mathrm{F} \bullet$ Mackay \& M•Seeger. (1989). Introduction to Bilingual Education.Beijing: Guangming press.

[5] Richards, J.C. \& Schnide, R. (2003). Longman Dictionary of Language Teaching and Applied Linguistics. Shanghai: Foreign language teaching and Research Press.

[6] Thomas, W.P., \& Collier, V.P. (1997). Two languages are better than one. Educational Leadership, 4, 23-26.

Jian Li was born in Heilongjiang, China in 1966. She received her Master degree in English Department, Harbin Normal University, China in 2002.

She is currently an associate professor in the School of Foreign Languages, Northeast Petroleum University, Heilongjiang, China. Her research interests include Teaching Methodology of English as a Foreign Language and American literature.

Miss Li is a Managing Director of Foreign Language Institute of Daqing City China; Member of Translators Association of Heilongjiang Province China; Member of Writers Association of Daqing City China.

Kunming Yao was born in Heilongiiang, China in 1966. He received his Master degree in School of Foreign Languages of University of Canberra in 2009. 
He is currently an associate professor in the School of Foreign Languages, Daqing Normal University, Heilongjiang, China. His research interests include Teaching Methodology of English as a Foreign Language and Second Language Acquisition and Pedagogy.

Mr Yao is a Managing Director of Foreign Language Institute of Daqing City China; Member of Translators Association of Heilongjiang Province China. 